NHS in its current form.) Finally, the fourth principle, that of keeping costs as low as possible, provokes a savaging of the QALY (Quality Adjusted Life Year), with some related and telling points along the way. As he says, we should be wary of accepting the economists' simplifying assumptions when the problems are more than just academic exercises. He also shows that, as measures of disability and distress, QALYs are only arbitrarily restricted to illness.

The aim of the book is admirable and anyone seriously interested in the future of the NHS needs some familiarity with the issues that it covers. Whether they acquire it via this book, or try elsewhere, may well depend on their reaction to its rather busy presentation. Sub-headings, numberings, lists, italics, emboldening, italicised emboldening, indenting, dialogue, diagrams and boxes all rush to help us. Ungrateful readers may soon be longing for a stretch of quiet, open country, disturbed only by the warble of a distant chapter, or the rustle of a new paragraph.

HUGH UPTON

Centre for Philosophy and Health Care, University College of Swansea

\section{Genes and human self-knowledge}

Edited by Robert F Weir, Susan C Lawrence and Evan Fales, Iowa City, University of Iowa Press, 1994, 248 pages, $\$ 14.95$ sc, $\$ 29.95 \mathrm{hc}$

Advances in molecular biology have allowed the identification of genes involved in an escalating number of diseases. Not only have the genes for monogenic conditions such as Cystic Fibrosis, Huntington's disease and Muscular Dystrophy been identified, but also the genetic components of common diseases such as heart disease, cancer and diabetes mellitus are now being characterised. This rapidly changing state of genetic 'knowledge' has profound social, ethical, practical and health economic implications. Individuals can discover whether they are at risk of, or likely to develop, a disease at some point in their lives, many years before the onset of actual symptoms. This is likely to change how people are viewed by themselves and by others, such as, for example, insurance companies and employers.

One of the problems with this rapidly expanding state of scientific knowledge is that it may outstrip understanding of the impact of such testing on individuals. Scientists may have an insufficient knowledge or interest in ethics, philosophy or psychosocial issues, and vice versa, yet this is an area that clearly requires an interdisciplinary approach. Genes and Human Self Knowledge is the publication of the proceedings of a four-day symposium held at the University of Iowa in 1992, which attempts to provide this interdisciplinary approach. The symposium gathered together experts from several different areas; philosophers, historians, biomedical ethicists, molecular genetic scientists, clinical geneticists and members of the general public to address various aspects of human genetics with special reference to the impact of the Human Genome Project (HGP) on these aspects. The book is organised into three sections, containing the symposium papers in revised essay form. Each essay is followed by one or more shorter sections representing responses or comments by panellists.

Essays in the first section address 'Genetic identity and self-knowledge' and suggest that the HGP may affect views on equality, normality and personal responsibility for conduct. Another essay, by a psychologist, uses personal and very moving statements by people at risk of developing Huntington's disease. Section two addresses possible uses and misuses of genetic knowledge. This includes an essay on the different understandings and implications of the term eugenics, both now and historically. Other essays discuss the teaching of molecular biology in schools and colleges and the role of the media in shaping the public's opinions and understanding of genetics. Discrimination based on the results of genetic tests (diagnostic or prognostic) by employers and insurers is also covered. The last section considers the theme 'Genders, races and future generations' and discusses the basis for beliefs of racial and sexual differences as well as the importance of genetic variation.

Although this book describes many of the facts in relation to genetic information from an American point of view, the fundamental issues raised are universal. There is some repetition of issues between different essays, but they are all very readable and it is good to see essays on philosophical discussions intermingled with personal accounts of a genetic condition and with essays considering the biology of genetics. I would recommend this $\frac{2}{\infty}$ book to those interested in the special $\stackrel{\AA}{\complement}$ ethical issues surrounding genetic testing.

ANNEKE LUCASSEN

Department of Clinical Genetics, Churchill Hospital, Oxford

\section{Reports from the Holocaust: the making $\stackrel{\triangle}{\triangle}$ of an AIDS activist}

Larry Kramer, London, Penguin, 1990, 290 pages, $£ 5.99$

A book such as this emerges from the deepest sense of indignation against a v society that struggles acrimoniously $\overrightarrow{\vec{H}}$ with the acceptance of homosexuality. is Larry Kramer has raised his voice of OI protest for over a decade, directing his rage at American politicians and 3 members of the medical establishment $\overrightarrow{-}$ who allegedly have been too slow in responding to the AIDS crisis. Kramer uses every expletive available $\stackrel{\text { क }}{+}$ - and then some - in these collected $\vec{\theta}$ speeches and editorials, many 8 published previously in journalisig. protest. A large number of these seething diatribes are directed at American Food and Drug Admint stration (FDA) for moving too conservatively on new interventions into the $\frac{\mathbb{Q}}{2}$ HIV-AIDS continuum. Countless times, Kramer compares what 'they' $\underline{\partial}$ are doing to homosexuals with the Nazi Holocaust. Critically-minded readers will find much to be critical of in Kramer's assertions, but this is protest literature intended to provoke $\widehat{\Phi}$ a response rather than scholarly praise.

While there may have been a tardi- 8 ness in the American political and 3 medical response to AIDS, the facto remains that as of yet this is an epidemic for which medical science $\frac{7}{8}$ offers no cure. It is most interesting to read Kramer's essays as furthering a $\widetilde{N}$ life-conserving tie between sex and love. Kramer rejects the libertarian 0 image of casual sex unrestrained by the absence of love. He offers a romantic notion of love that provides sex with a necessary and essential con- $\frac{\tau}{0}$ text. The stereotype that homosexuals are more promiscuous than heterosexuals is repudiated, although ${ }^{-}$ Kramer allows that promiscuity can $\underset{\mathbb{D}}{\mathbb{D}}$ arise in response to societal scorn.

This is an extremely controversial $\stackrel{\mathbb{Q}}{\Omega}$ book, full of rough language and heavy indictments, rooted in the deep pain of the destruction of loved ones. 